\title{
Advanced lines of Jalapeño pepper with potential for mechanical harvesting
}

\section{Lucas Matias Gomes ${ }^{*}$ (iD) Cláudia Silva da Costa Ribeiro ${ }^{2}$ Carlos Francisco Ragassi ${ }^{2}$ Lorena Sousa Silva ${ }^{4}$ Francisco José Becker Reifschneider ${ }^{3}$}

\author{
${ }^{1}$ Departamento de Genética e Melhoramento de Plantas, Universidade Federal de Goiás (UFG), Av. Esperança, 74.690-900, Goiânia, GO, \\ Brasil. E-mail: lucasmatyasgomes@gmail.com."Corresponding author. \\ ${ }^{2}$ Embrapa Hortaliças, Brasília, DF, Brasil. \\ ${ }^{3}$ Empresa Brasileira de Pesquisa Agropecuária, Secretaria de Relações Internacionais, Brasília, DF, Brasil. \\ ${ }^{4}$ Curso de Agronomia, Faculdades Integradas ICESP Promove, Brasília, DF, Brasil.
}

\begin{abstract}
The objective of this study was to evaluate the plant and fruit characteristics in advanced lines of Jalapeño pepper for mechanical harvesting. Thus, two experiments were carried out in the field. Experiment I (2015) was conducted as a randomized block design (three replications and eight plants per plot) and Experiment II (2016) in a completely randomized design (five replications and ten plants per plot). In 2015, lines CNPH 30,112, CNPH 30,118, CNPH 30,147, CNPH 30,159, CNPH 30,183, and CNPH 30,245 were evaluated, together with the control 'BRS Sarakura'. Significant differences were detected for fruit and plant characteristics $(P<0.05)$. Lines $C N P H 30,118, C N P H$ 30,147, CNPH 30,159, and CNPH 30,245 were selected based on plant height and height of the first bifurcation, earliness, and yield. They were evaluated again in 2016, together with 'BRS Sarakura' and 'Jalapeño Plus $F_{1}$ ' as controls. In 2016, CNPH 30,159 and CNPH 30,118 were selected due to their potential for mechanical harvesting. They were evaluated for height of the first bifurcation (>10cm), large fruits (11 cm $\times 4 \mathrm{~cm}$ ), high pulp firmness $(11 \mathrm{~N})$, wall thickness (about 5mm), and content of capsaicinoid substances (>50,000 SHU). Selected lines are undergoing additional field evaluation for mechanical harvesting with the Etgar Moses 1010 pepper harvester.
\end{abstract}

Key words: Capsicum annuum L., capsaicinoids, breeding, earliness, processing, soluble solids.

Linhagens avançadas de pimenta Jalapeño com potencial para a colheita mecanizada

RESUMO: $O$ objetivo desse estudo foi avaliar as características de planta e fruto em linhagens avançadas de pimenta do tipo Jalapeño visando à colheita mecanizada. Assim, foram feitos dois experimentos em campo. O Experimento I (2015) foi conduzido em delineamento de blocos casualizados (três repetições e oito plantas por parcela) e o Experimento II (2016) em delineamento inteiramente casualizado (cinco repetições e dez plantas por parcela). Em 2015, foram avaliadas as linhagens CNPH 30,112, CNPH 30,118, CNPH 30,147, CNPH 30,159, CNPH 30,183 e CNPH 30,245, juntamente com o controle 'BRS Sarakura'. Foram detectadas diferenças significativas para as características de planta e fruto $(P<0,05)$. As linhagens $C N P H 30,118, C N P H 30,147, C N P H 30,159$ e CNPH 30,245 foram selecionadas com base nas alturas da planta e da primeira bifurcação, precocidade e rendimento. Elas foram novamente avaliadas em 2016, juntamente com os controles 'BRS Sarakura'e 'Jalapeño Plus $F_{1}$ '. Em 2016, as linhagens CNPH 30,159 e CNPH 30,118 foram selecionadas com potencial para a colheita mecanizada. Elas foram avaliadas para altura da primeira bifurcação (>10cm), frutos grandes (11 cm x $4 \mathrm{~cm})$, polpa de elevada firmeza (11 $N)$, espessura de parede (5mm) e teor de substâncias capsaicinóides (>50.000 SHU). As linhagens selecionadas estão passando por avaliação adicional em campo para colheita mecânica com a colhedora de pimentas Etgar Moses 1010.

Palavras-chave: Capsicum annuum L., capsaicinóides, melhoramento, precocidade, processamento, sólidos solúveis.

\section{INTRODUCTION}

In Brazil, cultivation of the Jalapeño pepper has increased in the last years, mainly in regions near sauce processing industries. In the Municipality of Ouvidor (GO), where there is a pepper sauce industry, more than 2,000 t of 'BRS Sarakura' pulp were produced in 2015 (EMBRAPA, 2015). In the short and medium term, the scarcity of rural labor to harvest crops in this region may make it impossible to expand the crop and processing industries, which depend on the supply of raw materials. Recently, the USA has experienced a similar situation and mechanization of the harvest has been the alternative found to keep the productive chain of peppers viable. The cost of manual harvesting has reached $50 \%$ of the total cost of pepper production, whereas mechanization was reduced to less than 10\% (FUNK et al., 2011). Thus, development of cultivars more adapted to mechanical harvesting became a routine activity in breeding programs, 
especially at the New Mexico State University (NMSU). In the USA, Jalapeño fruit harvest has been almost entirely mechanical, and mechanical harvest of pepper for paprika has reached $80 \%$ of the area where it is cultivated (FUNK \& WALKER, 2009; FUNK \& WALKER, 2010), allowing these producers to maintain their competitiveness (UCHANSKI \& BLALOCK, 2013). In this context, some characteristics should be considered in the process of pepper plant selection for mechanical harvest, such as: higher plant and first bifurcation heights, larger stem diameter, erect growth habit, absence or few lateral shoots, well-developed root system, fruits easy to detach and with thick wall, narrow angle between branches, and fruit concentration in the upper third of the plant (WALL et al., 2003; FUNK et al., 2011). At the same time, the processing industry requires mature fruits, with color and firmness specific characteristics, capsaicinoid content, soluble solids content, and total titratable acidity, which should be considered in the breeding program. The objective of this study was to evaluate and select advanced Jalapeño pepper lines, with characteristics directed to mechanical harvesting that can meet the quality criteria of the fruit processing industry.

\section{MATERIALS AND METHODS}

\section{Lines evaluated}

The advanced Jalapeño lines evaluated in this study were selected from populations obtained from crosses between 'BRS Sarakura' and 'BRS Garça' with $C$. annuum short-cycle genotypes. The 'Genealogical' breeding method was adopted (ALLARD, 1971). The genotypes were evaluated in two field experiments at Embrapa Hortaliças, Brasília, DF (1555'57.31'S, 48 8'11.36”W, and altitude of $997 \mathrm{~m}$ ), with Aw-type climate. Experiment I was carried out in the period May-Oct 2015, with a monthly mean temperature in the range $15.4-32.4^{\circ} \mathrm{C}$, relative air humidity of $25-90 \%$, and total rainfall of $203 \mathrm{~mm}$. Experiment II was carried out in the period Feb-Aug 2016, with a monthly mean temperature in the range of $15.0-29.4^{\circ} \mathrm{C}$, relative air humidity of $27-90 \%$, and total rainfall of $325 \mathrm{~mm}$. Planting fertilization was done based on the soil analysis and recommendations of RIBEIRO et al. (2008). Both experiments were performed with spacing of $0.6 \mathrm{~m}$ between rows and $0.35 \mathrm{~m}$ between plants.

\section{Experiment I}

The lines $\mathrm{F}_{4}$ CNPH 30,112, CNPH 30,118, CNPH 30,147, CNPH 30,159, CNPH 30,183, and CNPH 30,245 were evaluated in comparison with the
'BRS Sarakura' control. A complete randomized block design was used, with three replications and eight useful plants per plot. The following characteristics were evaluated: precocity, heights of plant (m) and first bifurcation $(\mathrm{cm})$, numbers of lateral sprouts and fruits per plant, and mass of fruits per plant $(\mathrm{kg})$. Earliness, expressed in days after sowing (DAS), was determined when $50 \%$ of plants in the plot presented open flowers. Heights were measured using a line from ground level to the highest branch (for plant height) and first bifurcation (for height of first bifurcation). Sprouts that developed from plant lap (ground level) to the first bifurcation were counted to determine the number of lateral shoots.

\section{Experiment II}

The lines CNPH 30,118, CNPH 30,147, CNPH 30,159, and CNPH 30,245, which were selected in Experiment I, were evaluated together with 'BRS Sarakura' and 'Jalapeño Plus $F_{1}$ '. In all variables evaluated in Experiment I, significance was not observed in the block effect. Thus, Experiment II was conducted in a completely randomized design, with five replications and 10 useful plants per plot. All traits evaluated in Experiment I were considered in this experiment, except the number of lateral shoots. In addition, the characteristic height $(\mathrm{cm})$ of the lowest fruit was measured between the soil level and fruit peduncle insertion in the plant. Evaluation of precocity, expressed in days after transplanting (DAT), was carried out when $50 \%$ of plants in the plot had at least one fully mature (red) fruit.

Characteristics of fruits: individual fruit mass, fruit length and diameter, and wall thickness (RIBEIRO et al., 2017) were evaluated, but fruit diameter was evaluated only in Experiment I. For all these characteristics, different numbers of fruits per genotype were evaluated in Experiments I (45 fruits) and II (50 fruits).

Physical-chemical analyses of fruits: In both experiments, mature fruit color, fruit firmness, $\mathrm{pH}$, soluble solids, titratable acidity (15 fruits per genotype), and total capsaicinoid content (30 fruits per genotype) were analyzed. In Experiment II, different numbers of fruits per genotype were used to evaluate color (25 fruits) and firmness (50 fruits) of fruit. Five fruits per genotype were used to determine $\mathrm{pH}$, soluble solids, and titratable acidity. Fruit color (expressed by the $a^{*} / b^{*}$ ratio, for fruitredness degree), soluble solids, and capsaicinoid content were obtained as described by RIBEIRO et al. (2017). Pulp firmness was measured in the equatorial region of fruits using a digital penetrometer (INSTRUTHERM ${ }^{\circledR}$, model 
PTR-300) with a 5-mm pointer, according to the method described by MORETTI (2006). The $\mathrm{pH}$ value was determined potentiometrically using a $\mathrm{pH}$ meter (INSTRUTHERM ${ }^{\circledR}$, model PH-2000) using an official methodology (MAPA, 2010). The total titratable acidity was expressed in grams of citric acid/100 mL according to the methodology of MAPA (2010).

\section{Statistical analysis}

In both experiments, residuals normality was checked for each characteristic using the Anderson-Darling test at 5\% probability level. When the residual normality assumption was violated (Individual fruit mass, IFM; Fruit diameter, FD; and Pulp firmness, PF), data were transformed using the BOX \& COX (1964) methodology to stabilize or reduce existing variability and normalize residues. For the data with normality of residuals and significant $\mathrm{F}$ test $(\mathrm{P}<0.05)$, the means were clustered using the $t$ test. The Kruskal-Wallis test was applied to data with non-normal residual distribution (Days after sowing, DAS; Days after transplanting, DAT; and Fruit length, FL), even after BOX \& COX (1964) transformation. The lateral sprout data and number of fruits per plant were transformed into $\sqrt{ }(\mathrm{x}+0.5)$.

\section{RESULTS AND DISCUSSION}

In Experiment I, significant difference was not observed for the characteristics of total titratable acidity $(\mathrm{p}=0.21 ; \mathrm{CV}=1.8 \%)$, soluble solids $(\mathrm{p}=0.19$; $\mathrm{CV}=4.0 \%)$, and $\mathrm{a}^{*} / \mathrm{b}^{*}$ ratio $(\mathrm{p}=0.20 ; \mathrm{CV}=3.5 \%)$. In Experiment II, differences were not detected for fruit mass plant $^{-1}(\mathrm{p}=0.09 ; \mathrm{CV}=18.2 \%), \mathrm{pH}$ $(\mathrm{p}=0.14 ; \mathrm{CV}=7.3 \%)$, total titratable acidity $(\mathrm{p}=0.7$; $\mathrm{CV}=12.2 \%)$, and $\mathrm{a}^{*} / \mathrm{b}^{*}$ ratio $(\mathrm{p}=0.05 ; \mathrm{CV}=4.9 \%)$. For the other characteristics evaluated in both experiments, differences between lines were detected at 1 or $5 \%$ probability levels (Table 1 ).

\section{Plant evaluation}

In Experiment I, 'BRS Sarakura', CNPH 30,118 and CNPH 30,183 were the earliest genotypes (Table 1). In Experiment II, all lines were evaluated and grouped with 'BRS Sarakura' (Table 1). According to FUNK et al. (2011), selection of the earliest plants with a uniform and concentrated fruit maturation should be sought for the mechanical harvest to be successful. Based on the variability available in Experiment I, it was possible to select the earliest lines to continue the program. Plant height is a very important characteristic to develop cultivars adapted to mechanical harvesting (WALL et al., 2003), because tall and erect plants improve efficiency in this type of harvest (FUNK \& WALKER, 2010). Height in CNPH 30,112, among other lines, was significantly higher than that of the control (Table 1). In addition to genetic factors, plant height can be increased if plants are spatially arranged in the field. High planting densities can result in higher plants, providing increase in distance of the first fruits relative to soil surface, decrease in branch angles, and consequently better mechanical harvesting (WALL et al., 2003). Plants of sweet pepper for paprika, with greater height in the first bifurcation (FB) and few or no basal branches, increased efficiency in mechanical harvest (FUNK \& WALKER, 2010). In both experiments, cultivar BRS Sarakura, which is the commercial standard, was grouped with genotypes that showed the lowest mean values for this characteristic (Table 1). Mean values for FB in the range of $24.9-32.3 \mathrm{~cm}$ were obtained in cultivars of red pepper for paprika aiming mechanical harvest, being reported in the literature (WALL et al., 2003).

Although the mean values for $\mathrm{FB}$ in CNPH 30,112 were higher than those recommended for mechanical harvesting $(>10 \mathrm{~cm})$, this line was not selected for evaluation in Experiment II because it does not present desirable fruit characteristics. Height of the first fruit in relation to the soil level was evaluated only in Experiment II, presenting mean values in the range of $7.5-11.0 \mathrm{~cm}$ (Table 1). For mechanical harvest, selection is recommended in plants whose first set of fruits has both $10-\mathrm{cm}$ minimum height relative to soil level and fruits dispersed throughout canopy (FUNK et al., 2011). Table 1 shows that the mean values observed in CNPH 30,159 $(9.5 \mathrm{~cm})$ and CNPH $30,245(10.7 \mathrm{~cm})$ are equal or very close to the minimum value recommended in the literature. In the case of pepper plants, the lower the number of side shoots (SS) near soil surface, the better the mechanical harvesting efficiency (WALL et al., 2003), thus minimizing accumulation of branches and plants in the equipment. This characteristic was evaluated only in Experiment I, with mean values varying from 0.44 (CNPH 30,112) to 3.0 (CNPH 30,147) (Table 1). The lower and higher mean values for sprouting obtained in the present study are higher than those reported by WALL et al. (2003), who reported values in the range of 0.2-1.3 shoots per plant. Jalapeño-type pepper plants produced from 25 to 35 fruits (DEWITT \& BOSLAND, 2009), and this was also observed in the present study (Table 1). Line CNPH 30,147 was highlighted in both experiments, reaching mean values of 37 and 54 fruits plant ${ }^{-1}$ (experiments I and II, respectively). However, these values did not differ 
Table1 - Evaluation of genotypes of Jalapeño pepper regarding precocity (DAS, days after sowing; DAT, days after transplanting); Side shoots (SS); Plant height $(\mathrm{PH}, \mathrm{m})$; Height of the first fruit $(\mathrm{HFF}, \mathrm{cm})$; Height of bifurcation $\left(\mathrm{HB}, \mathrm{cm}^{2}\right.$; Number of fruits plant ${ }^{-1}$ (NFP); Fruit mass plant ${ }^{-1}$ (FMP, kg); Individual fruit mass (IFM, g); Fruit length and diameter (FL, cm, FD, cm); Pulp thickness (PT, mm), Pulp firmness (PF, N), Soluble solids (SS, $\%{ }^{\circ}$ Brix); Hydrogen ion potential of fruit $(\mathrm{pH})$, and Scoville heat units (SHU). Embrapa Hortaliças, Brasília, DF, 2015 and 2016.

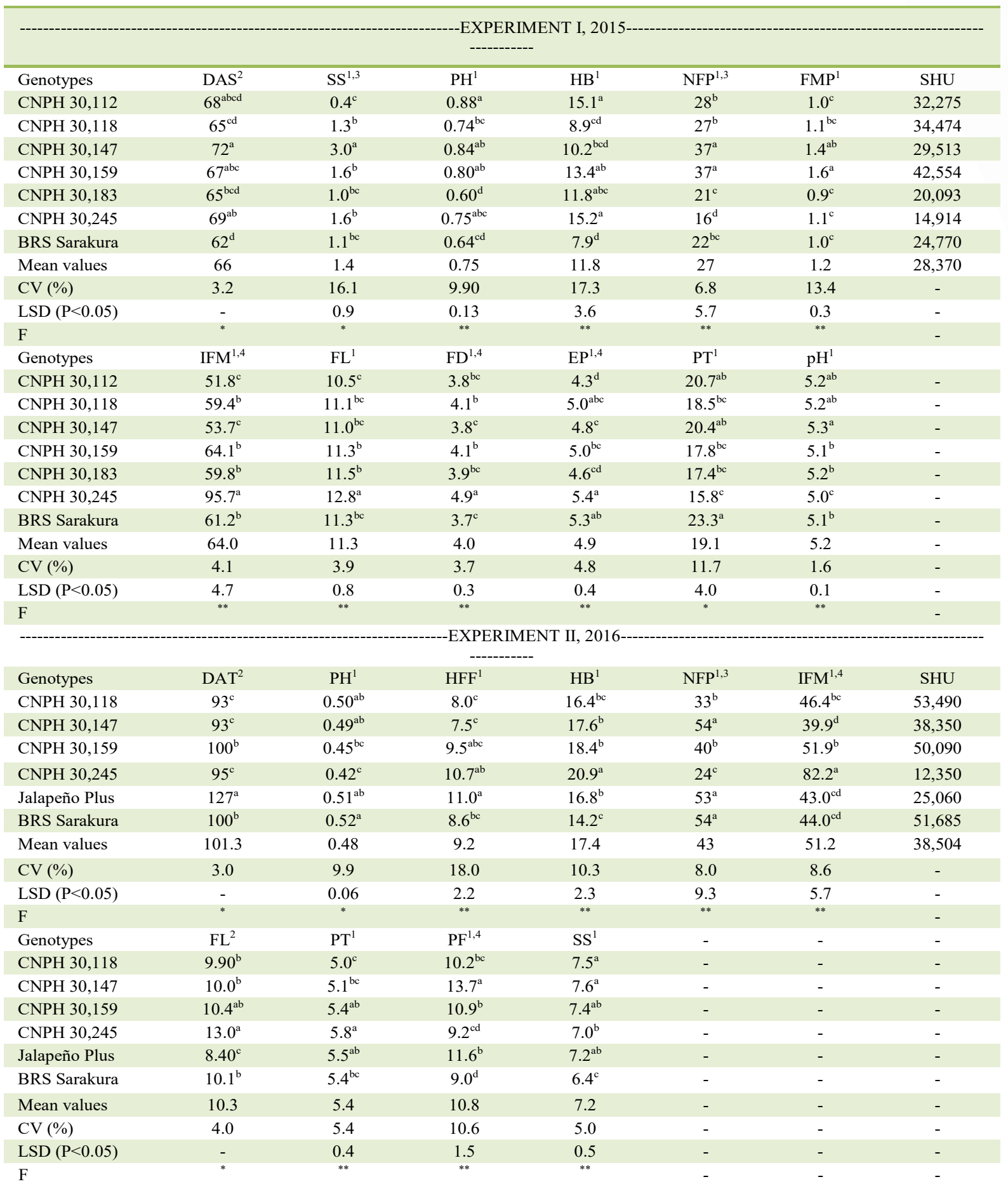

${ }^{* *}$ Significant at $1 \%$ probability level (F test); ${ }^{*}$ Significant at $5 \%$ probability level (F test); ${ }^{1}$ Data submitted to the $t$ test; ${ }^{2}$ Data submitted to the Kruskal-Wallis test; ${ }^{3}$ Data transformed to $\sqrt{\mathrm{x}+0.5}$, but the mean values were not transformed; ${ }^{\text {LSD }}$ Least significant difference; ${ }^{4}$ Data transformed by the Box-Cox method (1964). 
significantly from those observed in experiments I (CNPH 30,159) and II ('BRS Sarakura' and 'Jalapeño Plus $\mathrm{F}_{1}{ }^{\prime}$ ) (Table 1). Lines CNPH 30,147 and CNPH 30,159 showed the highest fruit masses plant $^{-1}$ in Experiment I (Table 1). Although line CNPH 30,245 had the lowest mean value for the number of fruits per plant, the fruit mass $(\mathrm{kg})$ per plant in this line was expressive in both experiments, as expected for the individual fruit size and mass. Taking into account the population density used in Experiments I and II $\left(47,600\right.$ plants $\left.h^{-1}\right)$, the highest average yield per hectare was $76 \mathrm{t} \mathrm{ha}^{-1}$ for line CNPH 30,159 (Experiment I), which was higher than that obtained by RIBEIRO et al. (2013) for cultivar BRS Sarakura $\left(60 \mathrm{tha}^{-1}\right)$.

\section{Characteristics of fruits}

Jalapeño fruits are usually large and have a thick wall, which ensures a higher pulp yield for sauce processing industries (DEWITT \& BOSLAND, 2009). Line CNPH 30,245 presented the highest mean values for all these fruit characteristics in both experiments (Table 1). The mean values for mass and size of 'BRS Sarakura' fruits reported in the present study are close to those reported by RIBEIRO et al. (2013) for this cultivar. All lines evaluated presented fruit size and pulp thickness compatible with what is required by processing industries. Regarding magnitude of the values obtained for pulp firmness, the difference found between the experiments may be related to the force applied to the penetrometer, since this analysis was done by different evaluators. Selection of Jalapeño pepper genotypes through the firmest ripe fruits may result in the lowest fruit damage during harvesting and transport to the industry and, thus, the lowest post-harvest loss and the best quality of raw material. The mean value for $\mathrm{pH}$ of fruits in the genotypes evaluated in Experiment I varied in the range of 5.0-5.3, and the $\mathrm{pH}$ value for line CNPH 30,245 significantly differed from those observed in other genotypes (Table 1). MENDOZA-SÁNCHEZ et al. (2015) evaluated physicochemical characteristics in Jalapeño fruits and reported a maximum value of 5.6 for $\mathrm{pH}$, which is slightly higher than the highest value (5.3) observed in the present study. In Jalapeño pepper fruits, the higher the soluble solids content, the higher the industrial yield and the lower the energy expenditure in the pulp concentration process during sauce manufacturing. A significant difference was observed between the values for soluble solids content only in Experiment II. The values for lines $\mathrm{CNPH}$ 30,118 and CNPH 30,159, selected in the present study, were grouped with the genotypes that resulted in the highest averages (Table 1), thus confirming the values obtained by MENDOZA-SÁNCHEZ et al. (2015). Line CNPH 30,245 presented the lowest mean values for capsaicinoid content in both experiments, whereas, CNPH 30,159 and CNPH 30,118 were highlighted as the highest values (Table 1).

\section{CONCLUSION}

Lines CNPH 30,159 and CNPH 30,118 present most of plant characteristics necessary to implement mechanical harvest and fruit characteristics necessary to produce high-quality sauces, being selected for additional evaluations with the pepper harvesting machine Etgar Moses 1010.

\section{ACKNOWLEDGEMENTS}

The authors are grateful to Sakura Nakaya Alimentos Ltda. for the financial support and to Conselho Nacional de Desenvolvimento Científico e Tecnológico $(\mathrm{CNPq})$ for the scholarships granted to Cláudia Silva da Costa Ribeiro and to Francisco José Becker Reifschneider. Furthermore, the authors are thankful to CNPq for the study grants awarded to first author Lucas Matias Gomes (Project Number: 800574/2014-1) and to Lorena Sousa Silva (Project Number: 800629/2016-7).

\section{DECLARATION OF CONFLICTING INTERESTS}

The authors declare no conflict of interest. The founding sponsors had no role in the design of the study; in the collection, analyses, or interpretation of data; in the writing of the manuscript, and in the decision to publish the results.

\section{AUTHORS' CONTRIBUTIONS}

All authors contributed equally for the conception and writing of the manuscript. All authors critically revised the manuscript and approved the final version.

\section{REFERENCES}

ALLARD, R. W. Princípios do melhoramento genético de plantas. São Paulo: Edgard Blüchner, 1971. 381p.

BOX, G. E. P.; COX, D. R. An analysis of transformations. Journal of the Royal Society, v.26, p.211-252, 1964. Available from: <http://www.jstor.org/stable/2984418>. Accessed: Dec. 27, 2018. doi: 10.1.1.321.3819.

DEWITT, D.; BOSLAND, P. W. The complete Chile pepper book: a gardener's guide to choosing, growing, preserving and cooking. London: Timber Press, 2009. 336p.

EMBRAPA. Contrato de parceria em pesquisa e desenvolvimento agropecuários (P\&D) entre Sakura-Nakaya alimentos LTDA, Embrapa e FAPED. Brasília: Embrapa, 2015, 24p. (Embrapa Cód. 10200.15/0001-8).

FUNK, P. A.; WALKER, S. J. Green chile pepper harvest mechanization. Annual ASABE meeting presentation. n. 095518, 14p, 2009. Available from: <https://elibrary.asabe.org/abstract.asp

Ciência Rural, v.49, n.2, 2019. 
?aid $=28552 \& \mathrm{t}=2 \&$ redir $=\&$ redirType $=>$. Accessed: Dec. 27, 2018. doi: $10.13031 / 2013.28552$.

FUNK, P. A.; WALKER, S. J. Evaluation of five green chile cultivars utilizing five different harvest mechanisms. Applied Engineering in Agriculture, v.26, p.955-964, 2010. Available from: <http://handle.nal.usda.gov/10113/48589>. Accessed: Dec. 27,2018 .

FUNK, P. A.; WALKER, S. J.; HERBON, R. P. A systems approach to chile harvest mechanization. International Journal of Vegetable Science, v.17, p.296-309, 2011. Available from: $<$ http://www.tandfonline.com>. Accessed: Dec. 27, 2018. doi: $10.1080 / 19315260.2010 .549167$.

MAPA - Ministério da Agricultura, Pecuária e Abastecimento. Manual operacional de bebidas e vinagres. 2010. Online. Available from: <http://www.agricultura.gov.br>. Accessed: Dec. 27,2018 .

MENDOZA-SÁNCHEZ, L. G. et al. Physicochemical and antioxidant properties of Jalapeño pepper (Capsicum annuum var. annuиm) during storage. Revista Chapingo Serie Horticultura v.21, n.3, p.229-241, 2015. Available from: < http://www.scielo. org.mx/pdf/rcsh/v21n3/v21n3a4.pdf>. Accessed: Dec. 27, 2018. doi: $10.5154 /$ r.rchsh.2015.06.010.

MORETTI, C. L. Protocolos de avaliação da qualidade química e física de tomate. Brasília: Embrapa Hortaliças, 2006. 12p. (Comunicado Técnico, n.32, 12p). Available from:https://www.agencia.cnptia.embrapa.br/Repositorio/ cot_32_000g13opcnq02wx5ok0xkgyq5s3bp107.pdf $>$. Accessed: Dec. 27,2018
RIBEIRO, C. S. C.; LOPES, C. A.; CARVALHO, S. I. C.; HENZ, G. P.; REIFSCHNEIDER, F. J. B. Pimentas Capsicum. Brasília: Embrapa, 2008. 200p.

RIBEIRO, C. S. C.; REIFSCHNEIDER, F. J. B.; CARVALHO, S. I. C. New Jalapeño-type cultivars developed by EMBRAPA, Brazil. In: XV EUCARPIA MEETING ON GENETICS AND BREEDING OF CAPSICUM.

AND EGGPLANT, 2013. Torino. Breakthroughs in the Genetics and Breeding of Capsicum and Eggplant. Torino, Itália: Eucarpia, v.15, p.435-437. Available from: <https://www. alice.cnptia.embrapa.br/alice/bitstream/doc/967088/1/0001.pdf $>$. Accessed: Dec. 27, 2018.

RIBEIRO, C. S. C. et al. Breeding Calabrian pepper lines for Brazilian agriculture from sui generis introduction of germplasm. Horticultura Brasileira, v.35, n.2, p.195-202, 2017. Available from: <http://www.scielo.br/pdf/hb/v35n2/1806-9991hb-35-02-00195.pdf $>$. Accessed: Dec. 27, 2018. doi.org/10.1590/ S0102-053620170207.

UCHANSKI, M. E.; BLALOCK, A. Ethephon improved pigmentation but had no effect on cayenne pepper fruit yield in southern New Mexico. HortScience, v.48, n.6, p.738-741, 2013. Available from: $<$ http://hortsci.ashspublications.org/content/48/6/738.full.pdf + html $>$. Accessed: Dec. 27, 2018

WALL, M. M. et al. Yield and quality of machine-harvested red chile peppers. HortTechnology, v.13 n.2, p.296-302, 2003. Available from: $<$ https://www.researchgate.net/publication/268052510>. Accessed: Dec. 27, 2018. 